\title{
Lucyna CHMIELEWSKA ${ }^{1}$
}

\section{FILOZOFIA POLITYCZNA JANA KALWINA}

\begin{abstract}
$\mathrm{W}$ artykule przedstawiono elementy filozofii politycznej Kalwina, powiązane $\mathrm{z}$ jego teologią, zawarte przede wszystkim w jego głównym dziele Nauka religii chrześcijańskiej. Założenie wszechmocy Boga stanowiło dla niego punkt wyjścia do rozważań również nad zagadnieniami z zasady niereligijnymi, takimi jak natura społeczeństwa, państwo czy problem nadużyć władzy politycznej. Uwagi Kalwina mają charakter normatywny wspólnie z ich pogłębioną analizą pozwala to zaliczyć je do filozofii politycznej. Jego myśl miała istotny wpływ na rozwój nowoczesnej polityki, dała początek charakterystycznemu dla nowoczesności rozdziałowi państwa i kościoła, wykształceniu się sfery świeckiej oraz zasadzie kontroli wobec sprawujących władzę..Punktem wyjścia dla tych rozważań była doktryna postlapsarianizmu, przede wszystkim będący jej następstwem radykalny rozdział sfery nadprzyrodzonej (sfery łaski) od sfery ziemskiej (natura). Choć Kalwin nie stworzył całościowego sytemu prawa natury, to jego rozważania dotyczące tej kwestii znacząco wpłynęły na myślenie polityczne. Gdy przyjmie się, że nowoczesna filozofia polityczna rozpoczyna się wraz z odrzuceniem Objawienia i oparciem się wyłącznie na racjach rozumu, można stwierdzić, że Kalwin jako teolog nie ma z nią żadnego związku. Przeciwny punkt widzenia zakłada natomiast, że poznanie nowoczesności nie jest możliwe bez zagłębienia się w zapoczątkowaną przez Kalwina tradycję religijną. Uważa się, że to, co zostało posiane jako reformacja, wykiełkowało politycznie w postaci antyrojalistycznych, wolnościowych ruchów, zmieniających rozumienie polityki. Pomiędzy tymi dwoma skrajnymi stanowiskami: tym, które odmawia Kalwinowi wpływu na nowoczesną politykę, a tym, które ten wpływ przecenia, mieści się całe spektrum pozycji pośrednich, według których teologia Kalwina i powiązana z nią filozofia polityczna odegrały istotną, ale bynajmniej nie jedyną, rolę w rozwoju nowoczesnej polityki. Niniejszy artykuł mieści się w tym właśnie spektrum.
\end{abstract}

Słowa kluczowe: Jan Kalwin, wspólnota polityczna, władza, łaska boża, prawo natury.

\section{WPROWADZENIE}

Przedmiotem zainteresowania filozofii politycznej nie jest to, jak świat polityczny faktycznie wygląda, lecz raczej to, jaki być powinien. Inaczej mówiąc, pole jej zainteresowania określają bardziej kwestie normatywne niż empiryczne. Jakie są uzasadnione i sprawiedliwe cele, do których należy dążyć, jakimi środkami można te uzasadnione i sprawiedliwe cele osiągnąć -to fundamentalne pytania, na jakie filozofia polityczna próbuje odpowiedzieć. Stanowią one przedmiot dyskusji myślicieli i filozofów politycznych od czasów starożytnych do współczesnych. Filozofia polityczna nie ogranicza się do definiowania fundamentalnych wartości i zasad, zajmuje się także analizą głównych pojęć istotnych dla polityki. Czy zatem Jan Kalwin (1509-1564) był twórcą filozofii politycznej? Trudno wyobrazić sobie postać, która wyrażałaby większą niż on dezaprobatę dla filozofii. Jednak krytykował filozofię przede wszystkim za jej rolę w

${ }^{1}$ Dr Lucyna Chmielewska, Wydział Studiów Międzynarodowych i Politologicznych, Uniwersytet Łódzki, ul. Składowa 41/43, 90-127 Łódź, e-mail:lucychmielewska@uni.lodz.pl 
scholastycznej teologii. Jego gwałtowność jako przedstawiciela fideizmu wynikała $\mathrm{z}$ przekonania, że racjonalizm niektórych scholastyków wyparł mądrość bożą zawartą w Biblii, że filozofia przesłoniła przesłanie zawarte w Objawieniu. Lektura głównego dzieła Kalwina, Nauki religii chrześcijańskiej, oraz komentarzy do ksiąg biblijnych pokazuje jednak, że nie odmawiał on znaczenia filozofii, ale dążył raczej do umiejscowienia jej w należnym jej miejscu, to znaczy w odniesieniu do spraw ziemskich. Kalwin był przede wszystkim teologiem i prawnikiem, ale był też renesansowym humanistą, pozostającym pod wpływem myśli filozofów starożytnych. Przy okazji rozważań teologicznych, dotyczących Boga, grzechu czy ludzkiego przeznaczenia, część z nich poświęcił zagadnieniom, które stanowiły przedmiot analizy filozofów starożytnych, takim jak państwo czy natura. W pismach Kalwina można zatem znaleźć: wskazówki co do pozycji i roli władzy świeckiej oraz jej relacji z kościołem, postulat kontroli sprawujących władzę, odniesienie do problemu tyranii.

\section{PAŃSTWO Z KONIECZNOŚCI, SPOŁECZEŃSTWO Z NATURY}

Jan Kalwin reprezentował drugą falę reformacji, był jednym głównych twórców protestanckiej tradycji reformowanej. Zasłynął jako autor Nauki religii chrześcijańskiej (pierwsze wydanie w 1536 r.), dzieła będącego próbą ustandaryzowania teorii protestanckiej, porównywanego niekiedy do Summy teologicznej Tomasza z Akwinu. Przejął i rozwinął główne założenia myśli Marcina Lutra, choć wprowadził do nich również elementy polemiczne, dotyczące chociażby pozycji władzy świeckiej i jej stosunku do kościoła. Charakterystyczne dla protestantyzmu było wyeksponowanie dogmatu o grzechu pierworodnym (postlapsarianizm) i związanego z nim przekonania o dogłębnym skażeniu natury ludzkiej. Stała się ona tym samym niezdolna do miłości Boga, co w świecie wyrażało się wyłączną skłonnością do zła. Dobro działo się natomiast wyłącznie za sprawą łaski Boga. Również ludzkie zbawienie pozostawało od niej zależne i nie miało związku z dobrymi uczynkami. Jak wierzono, Bóg predestynował znanych tylko sobie ludzi do zbawienia. W protestantyzmie, w przeciwieństwie do obowiązującego wówczas tomizmu, nastąpiło wyraźne oddzielenie łaski bożej, odnoszącej się do dziedziny ludzkiej duszy, od naturalnego statusu świata i ludzi, pozostającego naznaczonym dziedzictwem grzechu pierworodnego.

Wobec tego stanu rzeczy koncepcja władzy politycznej nie mogła być rozważana $\mathrm{w}$ oderwaniu od postlapsarianizmu. Pozostawała w związku z ludzką kondycją, będącą następstwem upadku pierwszych rodziców. Według Kalwina wobec obecnego w ludzkim świecie zła rząd świecki jako narzędzie dyscyplinujące stawał się koniecznością. Podążając za świętym Augustynem w komentarzu do Pawłowego listu do Rzymian, pisał, że rząd ustanowiony został przez Boga, by powstrzymywać samowolę niegodziwych i zapewnić spokój i ochronę niewinnym ${ }^{2}$. Koncepcja sfery politycznej pozostawała w związku z zapoczątkowaną przez Marcina Lutra, a pogłębioną przez Kalwina, dychotomią natury i łaski. Natura człowieka za sprawą grzechu pierworodnego uległa nie zranieniu, jak to przedstawiał tomizm, lecz zupełnemu zepsuciu. Ludzki rozum i wola stały się władzami zepsutymi, dlatego nie sposób było mówić o prawdzie ludzkiego poznania i wolności działań ludzkich. Rozum bezradny w kwestii poznania prawdy jest ślepy i

\footnotetext{
${ }^{2}$ J. Calvin, Commentaries on the Epistle of Paul the Apostle to the Romans, red. Rev. J. Owen, Christian Classics Ethereal Library, Grand Rapids, 13:3-4,s. 419, http://www.ccel.org/ccel/calvin/calcom38.pdf, 14.11.2012.
} 
pozbawiony wiedzy, nie może więc wskazywać woli rzeczy prawych, przez co człowiek nie jest w stanie czynić dobra. Rozum tkwi w błędzie, dlatego też wola jest zepsuta. Z tego głębokiego pesymizmu antropologicznego wynikała teza o wierze, będącej wyrazem bożej łaski, jako jedynej zasadzie zbawienia oraz o bezwartościowości ludzkich uczynków ${ }^{3}$. W tak ujętym porządku zbawienia prawo natury wydawało się zbędne, rozważane było jako nieodnoszące się do kwestii zbawienia, a wyłącznie dodoczesności. Stanowisko to miało związek $\mathrm{z}$ teorią dwóch królestw, opartą na zerwaniu jedności pomiędzy światem naturalnym i nadnaturalnym. Cel królestwa duchowego, zbawienie poprzez wiarę, nie łączył się z celem królestwa ziemskiego- naturalnym życiem człowieka. W królestwie duchowym rządy należały do słowa bożego, świat doczesny miał funkcjonować na podstawie prawa natury i prawa stanowionego ${ }^{4}$.

Państwo stanowiło element świata ziemskiego, dla którego normę postępowania miało stanowić prawo natury. Kalwin definiował prawo natury jak doczesną formę prawa bożego, uosabiającego sprawiedliwość - zasadę i cel wszystkich praw. Jak wierzył, prawo natury było wyrazem woli Boga (woluntaryzm), odbitym w ludzkich umysłach, choć jego rozumienie zaciemniało dziedzictwo grzechu pierworodnego ${ }^{5}$. Wola natomiast pozostawała zupełnie niezdolna do jego przestrzegania. Jako odzwierciedlenie prawa bożego prawo natury istniało jeszcze przed upadkiem pierwszego człowieka. W przekonaniu reformatora Bóg stworzył Adama ze zdolnością rozumienia i przestrzegania prawa natury, a zatem ze znajomością i odpowiedzialnością zeń wynikającą. Grzech pierworodny zaciemnił ludzkie pojmowanie prawa natury, choć człowiek pozostał zobowiązany do jego przestrzegania. Inaczej mówiąc, kiedy Adam zgrzeszył, zatracił zdolność poszanowania prawa natury, ale nie oznaczało to, że został z takiego obowiązku zwolniony. Potomkowie Adama odziedziczyli zarówno jego deprawację, jak i zobowiązanie wobec prawa natury. $\mathrm{Z}$ powodu grzechu pierworodnego ludzie nieustannie podejmowali próby rewizji i przekształcania prawa natury w celu dostosowania go do swojej upadłej woli. Zaciemnione przez grzech rozumienie prawa natury było przyczyną objawienia go w postaci prawa bożego (Biblia), korygującego niewłaściwe wysiłki natury ludzkiej. Ponieważ deprawacja zakłóciła ludzkie posłuszeństwo jako takie, zarówno wobec prawa natury, jak i prawa bożego, stąd uzasadnienie Kalwina dla stosowania prawa stanowionego przez rząd świecki i jego rola jako czynnika zabezpieczającego przed skutkami ludzkiego upadku6.

Kalwin określał prawo natury (lex naturae, natura dictat) jako prawo moralne ${ }^{7}$, jako naturalny porządek (naturae ordo) i światło natury, choć całościowego systemu prawa natury nie opracował. Uważał, że wskutek grzechu ludzki rozum nie jest w stanie poznać całego dobra, a prawo natury jest światłem sięgającym jedynie na tyle daleko, by

\footnotetext{
${ }^{3}$ J. Hervada, Historia prawa naturalnego, Petrus, Kraków 2013, s. 130.

${ }^{4}$ Ibidem, 131.

${ }^{5}$ J. Calvin, Institutes of the Christian Religion, tłum. H. Beveridge, Hendrickson Publishers, Peabody 2008,Book IV, Ch. 20:16.

${ }^{6}$ L.S. Koetsier, Natural Law and Calvinist Political Theory, Trafford Publishing, Bloomington 2004, s. 66.

${ }^{7}$ D.B. Forrester, Richard Hooker 1553-1600, [w:]History of Political Philosophy, red. L. Strauss, J. Cropsey, Rand McNally, Chicago 1963, s. 349-350. „Prawo moralne - pisał - [...] jest prawdziwą i wieczną zasadą sprawiedliwości, nakazaną ludziom wszystkich narodów i czasów, pragnących kształtować swoje życie zgodnie z wolą Boga. Jego wieczną i niezmienną wolą jest, abyśmy oddawali mu cześć i wzajemnie się miłowali” (J. Calvin, Institutes..., Book IV, Ch. 20:15).
} 
człowiek mógł zostać rozliczony za swe czyny. Prawo natury sprawiało zatem, że człowiek nie mógł czuć się zwolniony z odpowiedzialności. „Celem prawa natury - pisał -jest [...] osąd sumienia, rozróżniający pomiędzy tym co sprawiedliwe i niesprawiedliwe na tyle dostatecznie, by przez uświadomienie ludziom ich własnego statusu, pozbawić ich pretekstu niewiedzy" "Rozdział natury i łaski, uczynienie prawa natury podstawą funkcjonowania rzeczywistości ziemskiej, stanowił uzasadnienie dla separacji kościoła i państwa, co nie było jednak równoznaczne z separacją państwa i religii. Kalwin w rozważaniach na temat rządu świeckiego, jak sam przyznawał, zajmował stanowisko pośrednie pomiędzy „barbarzyńcami”, czyli anabaptystami, którzy chcieliby obalenia wszelkich form władzy ziemskiej, a ,pochlebcami książąt, wychwalającymi ich władzę bez umiarkowania"9, czyli luteranami. Nie godził się, z jednej strony, z brakiem władzy świeckiej i oparciem porządku społecznego wyłącznie na Ewangelii, z drugiej - z podporządkowaniem kościoła władzy świeckiego księcia. „Nie należy łączyć władzy duchowej i świeckiej - stwierdzał - są one od siebie wyraźnie oddzielone”, choć kościół i państwo nie są sobie przeciwne ${ }^{10}$. Rząd polityczny i rząd kościelny w opinii Kalwina nie różniły się w swej istocie, lecz celach, ich natura była bardziej analogiczna niż przeciwna. Rząd duchowy jest tak samo niezbędny do życia kościoła, jak rząd polityczny do sprawnego funkcjonowania społeczeństwa. Rodzaj władzy obecnej w kościele może nosić przydomek „duchowa”, ale to nie zmienia jej charakteru i nie czyni czymś diametralnie różnym od władzy świeckiej. Oba rodzaje są narzędziem dyscyplinującym i ochronnym zarazem. Ład, definiowany jako ,dobrze uregulowany ustrój, który wyłącza wszystko: zamieszanie, nieuprzejmość, upór, wrzaski i rozłamy”, miał być głównym celem rządu zarówno religijnego, jak i politycznego ${ }^{11}$. Wobec tego uzasadniona wydaje się uwaga o silnej świadomości politycznej w myśli Kalwina. W odniesieniu do jego eklezjologii można wręcz mówić o polityzacji kościoła, przy jego jednoczesnym odseparowaniu od polityki. Społeczność ludzka, w tym kościół -wydaje się mówić Kalwin -nie przypominała czegoś, co raz ustanowione, trwa nieprzerwanie, wymagała więc stałego sprawowania władzy. Podobnie jak ład wszechświata zachowywany był przez aktywne panowanie Boga, tak porządek ludzki, jeśli nie miał się stać domeną chaosu, musiał być podtrzymywany instytucją władzy.

Jak wspomniano Kalwinowi nie odpowiadało ani stanowisko luteranów, ani anabaptystów, rozróżnienie przez niego władzy duchowej i świeckiej służyło w istocie zachowaniu każdej z nich i obaleniu poglądu, że władza świecka jest złem, a duchowa jedynie formą perswazji ${ }^{12}$. Rozdział 20 czwartej księgi Nauki religii chrześcijańskiej, poświęcony władzy świeckiej, jest przede wszystkim polemiką $\mathrm{z}$ anabaptystami ${ }^{13}$,

\footnotetext{
${ }^{8}$ J. Calvin, Institutes..., Book II, Ch.2:22

${ }^{9}$ Ibidem, Book IV, Ch. 20:1.

${ }^{10}$ Ibidem.

${ }^{11}$ S.S. Wolin, Politics and Vision. Continuity and Innovation in Western Political Thought, Princeton University Press, Princeton 2006, s. 153.

${ }^{12}$ Ibidem, s. 153-154.

${ }^{13}$ Pierwsi reformatorzy protestanccy w swej krytyce Kościoła katolickiego odwoływali się pierwotnej koncepcji kościoła jako społeczności, połączonej więzami wiary i zjednoczonej we wspólnym dążeniu do zbawienia. Ten nacisk na wspólnotowy wymiar kościoła nawiązywał do dyskusji z okresu wczesnego chrześcijaństwa o wyższości formy społecznej nad formą polityczną. Formę społeczną charakteryzował brak realnych struktur władzy, wynikający z założenia, że ludzie mogą żyć w sposób uporządkowany w społeczności bez konsekwentnego stosowania władzy, być
} 
nazywanymi przez Kalwina „fanatykami” i „barbarzyńcami”. Anabaptyści wszelki porządek ziemski, w tym władzę i własność prywatną, uważali za sprzeczny z Ewangelią. Zakazywali chrześcijanom pełnienia urzędów i sprawowania władzy politycznej, powołując się na słowa ewangelisty Łukasza (22, 24-27), dotyczące pierwszeństwa („Powstał też między nimi spór o to, który z nich jest ważniejszy. Wtedy Jezus im powiedział: «Królowie narodów panują nad nimi, a ich władcy są nazywani dobroczyńcami. U was tak być nie może. Ale najważniejszy z was niech będzie jak najmłodszy, a przełożony, jak ten, który usługuje»"). Dla Kalwina słowa te nie negowały zasadności władzy królewskiej jako takiej, zaprzeczały jedynie jej apostolskiemu charakterowi ${ }^{14}$. Wizja porządku społecznego anabaptystów w oczach Kalwina uchodziła za anarchię, a oni sami, ze swym pragnieniem społeczności bez władzy, podobni byli jak stwierdzał -do „szczurów w słomie” ${ }^{15}$. Jako przeciwwagę dla argumentacji anabaptystów przytaczał słynny fragment Pawłowego listu do Rzymian (13, 1-3) (,Nie ma bowiem władzy, która nie byłaby od Boga; lecz każda, która istnieje, została ustanowiona przez Boga. Dlatego ten, kto sprzeciwia się władzy, występuje przeciw porządkowi Boga, a ci, którzy występują przeciw porządkowi, sami na siebie ściągają karę. Sprawujący władzę nie wywołują lęku u tych, co dobrze czynią, ale u tych, którzy czynią źle").

Nie będzie przesadą stwierdzenie, że Kalwin sakralizował władzę jako taką. Człowiek nie może wątpić, przekonywał, że władza polityczna jest nie tylko uświęcona i legalna, ale „najbardziej uświęcona i najbardziej zaszczytna” pośród wszystkiego, co dostępne jest człowiekowi w ramach jego doczesnego życia. Władza pochodzi od Boga, a sprawujący ją cieszą się boskim autorytetem, stąd należy im się szacunek ${ }^{16}$. Sprzeciw wobec władzy równoznaczny jest buntowi wobec Stwórcy, ustanawiającemu rząd świecki jako pomoc upadłej ludzkości. Rząd, stojący na straży przestrzegania prawa natury, w przekonaniu reformatora potrzebny był ludziom nie mniej niż „chleb i woda, światło i powietrze”. Jego podstawowym zadaniem było zabezpieczenie kultu religii chrześcijańskiej przed wrogami

członkami grupy społecznej, ale nie politycznej. Tendencje te przybrały radykalną formę we współczesnym luteranizmowi ruchu anabaptystów. Dominowała wśród nich troska o zachowanie czystości społeczności ich kościoła pośród - jak twierdzili - „brudnego”, skażonego grzechem świata. Anabaptyści starali się osiągnąć ten cel poprzez izolację swych społeczności i zaprzeczenie istnieniu jakichkolwiek ich zobowiązań wobec porządku politycznego. Innymi słowy - ,społeczny” charakter ich jedności miał być zachowany dzięki unikaniu kontaktu z ,,politycznym” otoczeniem. Krótka i brutalna dyktatura anabaptystów podczas wojny chłopskiej pod dowództwem Thomasa Müntzera wykazywała powinowactwo z podstawowymi ideami ruchu, choć pozostawała sprzeczna z anabaptystycznym ideałem unikania przemocy. Zwolenników Thomasa Müntzera motywowała tasama nienawiść do świata, przez ten sam antypolityczny impuls obecny w pokojowej wersji anabaptyzmu. Zamiast szukania ucieczki od „,złego” świata, müntzeryści reagowali w sposób podobny do niektórych siedemnastowiecznych grup purytańskich: za pomocą ,świętej przemocy” pragnęli pokonać skorumpowany świat, wykorzenić z niego błędne elementy i przekształcić go na wzór czystej komunii świętych. W krwawej czy pokojowej formie stałym elementem tej mentalności była antypolityczność (ibidem, s. 148-149).

${ }^{14}$ J. Calvin, Institutes..., Book IV, Ch. 20:7.

${ }^{15}$ Ibidem, Book IV, Ch. 20:5.

${ }^{16}$ Ibidem, Book IV, Ch. 20:4. Kalwin przywoływał między innymi cytat z księgi Przysłów (8, 1516): „Ze mną rządzą królowie i władcy wydają sprawiedliwe prawa. Ze mną sprawują władzę książęta i dostojnicy sądzą na całej ziemi”. 
zewnętrznymi, jak i przed wewnętrznymi zagrożeniami lekceważenia, profanacji czy publicznego bluźnierstwa ${ }^{17}$. Rząd świecki miał służyć temu, ,aby, spokój publiczny nie był zakłócany, aby własność każdego człowieka była bezpieczna, aby każdy człowiek mógł uczciwie handlować z innymi, aby mogły się rozwijać uczciwość i skromność; krótko mówiąc, aby mogła istnieć publiczna forma religii pośród chrześcijan oraz człowieczeństwo pośród ludzi"18. Wziąwszy pod uwagę założenie Kalwina o wszechmocności Boga ${ }^{19}$ jako przyczyny wszystkiego oprócz grzechu ${ }^{20}$, jego silnie zdeterminowaną wizję świata, rząd świecki nie mógł być kwestią przypadku czy zwykłym, ziemskim aparatem opresji ${ }^{21}$.

Odkrywanie przez człowieka prawa natury, będącego inną formą Objawienia, dokonywało się wspólnym wysiłkiem ludzkiego rozumu i sumienia, choć owo ,światło natury" odbierało głównie sumienie w postaci przeczuć i poruszeń2 ${ }^{22}$. Istnienie w ludzkim umyśle świadomości prawa natury zdradzała ludzka skłonność do życia w społeczeństwie. Człowiek,w odniesieniu do porządku doczesnego, wydawał się mieć zapisane w umyśle ogólne wzorce porządku obywatelskiego i uczciwości;,,[...]człowiek - pisał Kalwin - jest z natury zwierzęciem społecznym wykazuje instynktowną skłonność do pielęgnowania i ochrony społeczeństwa; a zatem widzimy, że w umysłach wszystkich ludzi zawarte są wrażenia obywatelskiego ładu i uczciwości"23. Społeczeństwo w ujęciu Kalwina miało zatem charakter naturalny, opierało się na właściwym człowiekowi instynkcie społecznym, tym samym, o którym pisał Arystoteles. Zatem, zauważał Kalwin, gdy niektórzy z ludzi dopuszczali się rabunków i morderstw, inni postrzegali to jako niesprawiedliwość ${ }^{24}$. Sprawiedliwość była istotą prawa natury, miała charakter naturalny ${ }^{25}$. Stąd brała się ogólna zgoda zarówno społeczeństw, jak i jednostek na to, by przyjmować prawa oparte za zasadzie sprawiedliwości i im podlegać. Sprawiedliwość, wyrażana w miłości bliźniego, stanowić miała nienaruszalną zasadę prawa stanowionego w każdym miejscu i czasie ${ }^{26}$. Człowiekowi właściwe było bowiem naturalne poczucie sprawiedliwości i porządku społecznego, obywające się bez wskazówek uczonych prawodawców. Zdaniem Kalwina był to kluczowy dowód na to, że nikt nie został pozbawiony światła rozumu $\mathrm{w}$ stosunku do życia doczesnego ${ }^{27}$. Prawo natury istniało zatem, lecz nie było światłem pochodzącym z dokonanego przez człowieka poznania, lecz darem Boga ukazującym człowiekowi Jego wolę $e^{28}$.

Grzech pierworodny zakłócił jednak społeczną naturę człowieka. Koniecznym elementem dyscyplinującym, umożliwiającym funkcjonowanie życia społecznego, stała się władza świecka. Idąc za wskazówkami Biblii, Kalwin nie faworyzował żadnego ustroju; w jego przekonaniu każda forma rządu, respektująca sprawiedliwość, mogła

\footnotetext{
${ }^{17}$ J. Calvin, Commentary on Daniel, Vol. 1, Ch. 4, Daniel 4:1-3.

${ }^{18}$ J. Calvin, Institutes..., Book IV, Ch. 20:3.

${ }^{19}$ Ibidem, Book I, Ch.16:3; Book II, Ch.4:6.

${ }^{20}$ Ibidem, Book I, Ch.14:16.

${ }^{21}$ S.S. Wolin, op. cit., s. 162.

${ }^{22}$ J. Calvin, Institutes ..., Book IV, Ch. 20:16.

${ }^{23}$ Ibidem, Book II, Ch. 2:13.

${ }^{24}$ Ibidem.

${ }^{25}$ Ibidem, Book IV, Ch.20:16.

${ }^{26}$ Ibidem, Book IV, Ch. 20:15.

${ }^{27}$ Ibidem, Book II, Ch.2:13.

${ }^{28}$ J. Hervada, op. cit., s. 132.
} 
zostać uznana za odpowiednią. Spośród trzech ustrojów, rozważanych przez starożytnych: monarchii, arystokracji i demokracji, preferował arystokrację ze względu na jej pośredni charakter. Jak stwierdzał, nie jest to ,władza sama w sobie, jak monarchia”, która łatwo może stać się tyranią, ani czysty rząd ludowy w postaci demokracji, skłonny do anarchii, lecz ustrój, którego główna zaleta tkwiła w możliwości narady i wspólnego osądu. Preferencja dla arystokracji miała kontekst postlapsariański. „Biorąc pod uwagę występki i wady ludzi - pisał - bezpieczniej jest i bardziej znośnie, jeśli różni dźwigają rządy, kiedy mogą sobie wzajemnie towarzyszyć, pouczać się i upominać; i żaden nie dysponuje możliwością pójścia za daleko, inni są cenzorami i nauczycielami hamującymi jego ekscesy"29. Wzajemna kontrola i upominanie stanowić miały zaporę przeciw arogancji rządzących. Kalwin wierzył w nie tak bardzo, że zapis o „braterskiej poprawce” włączony został do konstytucji kościoła w Genewie. W 1557 r. utworzona została Mała Rada, której zadaniem było upominanie rządzących na tajnych, cokwartalnych posiedzeniach „braterskiego wsparcia”.

W ujęciu reformatora posłuszeństwo rządzącym stanowiło konsekwencję traktowania władzy jeszcze w kategoriach sakralnych jako pochodzącej, wprawdzie pośrednio, ale jednak od Boga. Kalwin określał więc rządzących ,jako ministrów i ambasadorów Boga”,30. Panujący - pisał - jest „ojcem swojego kraju”, ,pastorem ludu”, „opiekunem pokoju”, „prezydentem sprawiedliwości”, „obrońcą niewinności”31. Te wszystkie szlachetne przymioty władzy wynikały z jej boskiej genezy, jednak mowa była tu nie o osobie, lecz urzędzie. Kalwin, na wzór starotestamentowy, traktował sprawujących władzę jako jej dzierżawców z woli Opatrzności i nie ich osoba, lecz instytucja (króla, księcia czy zgromadzenia) stanowić miała obiekt szacunku i posłuszeństwa. Reformator odróżniał rząd prawowity od tyranii, choć początkowo przekonywał, że również tyranom, sprzeniewierzającym się swojemu powołaniu do troski o wolność i bezpieczeństwo ludu, należy się szacunek, zważywszy na boską proweniencję sprawowanej przez nich funkcji ${ }^{32}$, a i sama osoba tyrana nie mogła być dziełem przypadku, zważywszy jak wielką wagę reformator przywiązywał do działania Boga w świecie. „Toteż - pisał w komentarzu do psalmu -należy również mieć na uwadze, że wszystkie zdarzenia mają miejsce za sprawą bożej Opatrzności i że nic nie dzieje się przez przypadek. [...] Bóg, podług swojego wiecznego zamiaru, zarządza wszystkim w taki sposób, że nic nie może być uczynione, jak tylko z jego woli i ustanowienia" ${ }^{33}$. Kalwin powielał przekonanie Augustyna o opresyjności władzy jako znaku bożego gniewu ikarze za grzechy ${ }^{34}$. Zalecał w takiej sytuacji postawę pokornej bierności: ,[...] jeśli jesteśmy okrutnie dręczeni przez dzikość, jeśli jesteśmy drapieżnie splądrowani przez chciwych, czy zamożnych, jeśli jesteśmy zaniedbani przez lenistwo, słowem, jeśli jesteśmy prześladowani dla sprawiedliwości przez bezbożnego i świętokradczego księcia, najpierw przywołajmy wspomnienie naszych błędów, które bez wątpienia Bóg każe takimi biczami. W ten

\footnotetext{
29 J. Calvin, Institutes ..., Book IV, Ch. 20:8.

${ }^{30}$ Ibidem, Book IV, Ch. 20:22.

${ }^{31}$ Ibidem, Book IV, Ch. 20:24.

${ }^{32}$ Ibidem, Book IV, Ch. 20:26-27.

${ }^{33}$ J. Calvin, Commentary on the Book of Psalms, thum. Rev. J. Anderson, t. 4, Christian Classics Ethereal Library, Grand Rapids,Ps. 115: 3, s. 310, http://www.ccel.org/ccel/calvin/calcom11.pdf, 23.04.2013; Idem, Institutes..., Book IV, Ch. 20:25.

${ }^{34}$ J. Calvin, Institutes..., Book IV, Ch. 20:25.
} 
sposób naszą niecierpliwość okiełzna pokora. I wspomnijmy, że nie do nas należy uleczenie tego zła, że wszystko, co nam pozostaje, to błagać o pomoc Boga, w rękach którego są serca królów i upodobania królestw"35. W komentarzu do księgi Daniela dowodził jednak, że pycha i okrucieństwo nie są godne boskiego pochodzenia władzy i bywają szybko ukrócone, jak pokazywał przykład biblijnego króla Nabuchodonozora, ukaranego przez Boga sprowadzeniem do stanu zwierzęcego. Drzewo z proroczego snu Nabuchodonozora interpretował jako symbol instytucji władzy, ustanowionej przez Boga dla pożyteczności ludzi, ich ochrony i bezpieczeństwa, na wzór drzewa w przyrodzie, dostarczającego pokarmu i schronienia dla ptaków i zwierzą ${ }^{36}$. Symbol ten odnosił jednak również do tyranów, ich rządy wydawały mu się, mimo wszystko, lepszą perspektywą niż anarchia $^{37}$.

W miarę nasilania się aktów agresji w stosunku do francuskich wyznawców kalwinizmu (hugenotów) reformator zrewidował nieco swoje stanowisko w kwestii tyranii i oporu wobec niej. Misję sprzeciwu wobec tyrana powierzał nie ludowi czy pojedynczym, prywatnym osobom, lecz pochodzącym z wyborów magistratom (populares magistratus). Kalwin uważał ich za kontynuatorów spartańskich eforów, rzymskich trybunów ludowych i ateńskich dekarchów, powoływanych w corocznych wyborach do upominania samowoli rządzący $\mathrm{ch}^{38}$. Nie tylko prawem, ale i obowiązkiem magistratów miało być przeciwstawianie się przemocy i okrucieństwu (łac. intercedere 'przechodzić pomiędzy') króla, w przeciwnym razie -pisał -,oszukańczo zdradzają wolność ludu, wiedząc, że bożym zarządzeniem ustanowieni zostali jej strażnikami”’”. Słowo intercedere oznaczać mogło szerokie spektrum działań od werbalnego upomnienia do fizycznego sprzeciwu; Kalwin nie precyzował tej kwestii, wspominał tylko o

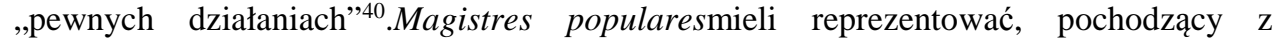
wyborów, niższy rodzaj władzy, służący ochronie wolności i bezpieczeństwa ludzi. Magistraci mieli stanowić rodzaj buforu, zabezpieczającego społeczeństwo przed nadużyciami ze strony państwa.

Nacisk położony przez Kalwina na kwestię ładu we wspólnocie politycznej skłaniał go w konsekwencji do przyznania, że nawet tyrania zachowywała elementy rządu i pod pewnymi względami była korzystniejsza dla społeczeństwa niż anarchia. Kalwin przedstawiał relację rządzących i rządzonych z jednej strony jako zasadniczo polityczną, opartą na normach prawa natury, $\mathrm{z}$ drugiej - włączał obie strony w relację z Bogiem. Władca traktowany był jako pełniący przejściowo boski urząd władzy $\mathrm{i}$ odpowiedzialny $\mathrm{w}$ tej kwestii przed Bogiem, lud natomiast winny był wykonywania jego poleceń. Posłuszeństwo było zatem obowiązkiem zarówno politycznym, jak i religijnym. Na poziomie ludzkim wspierało realizację celów cywilizowanego społeczeństwa (sprawiedliwości), na poziomie religijnym służyło poszukiwaniu właściwej relacji z

\footnotetext{
${ }^{35}$ Ibidem, Book IV, Ch. 20:29.

${ }^{36}$ J. Calvin, Commentary on Daniel, Vol. 1, Ch. 4, Daniel 4:13-16.

${ }^{37}$ Ibidem.

${ }^{38}$ Q. Skinner, The Foundations of Modern Political Thought, t.2:The Age of Reformation, Cambridge University Press, Cambridge 2004, s. 232.

${ }^{39}$ J. Calvin, Institutes..., Book IV, Ch. 20:31.

${ }^{40}$ W. R. Stevenson, Jr., Calvin and Political Issues, [w:]The Cambridge Companion to John Calvin, red. D.K. McKim, Cambridge University Press, Cambridge 2004, s. 184-185.
} 
Bogiem ( władza świecka miała chronić kościół od zagrożeń) ${ }^{41}$. W wypadku tyranii dominujący był element religijny. Tyrania potraktowana została przez Kalwina jako środek bożego gniewu, służący „biczowaniu” społeczności za popełnione grzechy. Pojawienie się tyrana miało skłaniać ludzi do rachunku sumienia i poczucia winy. Stosunek między obywatelem i tyranem nie należał zatem do poziomu politycznego,lecz do kategorii „niebieskiej”, ponieważ pojęcie grzechu, łączące tyrana i poddanych, nie było (i nie jest) kategorią polityczną ${ }^{42}$. Pomimo intencji Kalwina, by uzasadnić posłuszeństwo wobec tyrana, efekt jego rozumowania okazał się odmienny od zamierzonego. $\mathrm{Z}$ racji niezwykłego charakteru tyranii należało ją wyizolować z normalnych stosunków politycznych. Tyran, podniesiony do roli boskiego posłannika, chłoszczącego grzeszników, pełni misję zasadniczo apolityczną. Grzech jako taki nie przynależy bowiem do stosunków politycznych. Tendencja do wyprowadzania tyranii poza zwykłe stosunki polityczne pojawiała się ponownie, gdy Kalwin rozważał problem posłuszeństwa. W posłuszeństwie wobec tyrana lojalny poddany postrzegany był przede wszystkim jako grzesznik, wypełniający obowiązki wobec Boga, a nie wobec społeczeństwa. Posłuszeństwo tyranowi było jednak ograniczone nakazami sumienia, to znaczy przez inny czynnik pozapolityczny. Chociaż sumienie tworzyło bezpośredni związek między jednostką a Bogiem i tym samym umożliwiało obejście politycznych relacji pomiędzy władcą a poddanymi, to jednak stwarzało poważne zagrożenie dla nieograniczonych roszczeń tyrana. Sumienie to pojęcie religijne, jednak w koncepcji Kalwina wykorzystane zostało w celach politycznych, bez ograniczania jego zasadniczego znaczenia. W pewnym sensie działanie sumieniastanowiło odpowiedź na władzę; rządzący miał do czynienia z jednostką jako obiektem przymusu w porządku politycznym, jednak protest sumienia wobec łamiącego prawa boskie i ludzkie tyrana stanowił wyraz jej bezpośredniej relacji z Bogiem. Tym samym ,sąd sumienia” czynił z osoby politycznie zaangażowanego obywatela, który ze względów religijnych i ludzkich nie stosował się do poleceń, sprzeciwiających się prawu natury (równoznacznemu objawionemu w Biblii prawu bożemu).W ujęciu Kalwina paradoks polegał więc na tym, że sumienie sprzeciwiało się tyranii, uznawanej za wyraz bożego gniewu, że wypełniało tym samym obowiązek wobec Boga (tyran łamał wszak prawo boże) i przypominało władcy o prawdziwej naturze jego urzędu - realizacji zasady sprawiedliwości, będącej kwintesencją prawa natury ${ }^{43}$. Kluczowa pozycja w teorii oporu Kalwina przeznaczona została zatem dla ludzkiego sumienia w imię integralności politycznej, broniącego prawa bożego. Koncepcja oporu wobec tyranii u Kalwina wykazywała tym samym, większą niż u innych reformatorów, wrażliwość na implikacje polityczne. W istocie motywowana była ona racjami nie religijnymi, lecz politycznymi ${ }^{44}$. Projekt urzędu magistratów miał charakter polityczny, ich sprzeciw wobec przemocy tyranów i ochrona ludzi zależały w istocie od osądu ich sumienia. Pod koniec życia reformator zaczął skłaniać się ku przekonaniu, że relacja króla $\mathrm{z}$ poddanymi powinna mieć charakter bardziej sformalizowany -na wzór starotestamentowych przymierzy, zawieranych pomiędzy królami i ludem izraelskim. Uważał, że przysięgi koronacyjne i prawa krajowe tworzą taki rodzaj umów, których

\footnotetext{
${ }^{41}$ Ibidem, s. 167.

${ }^{42}$ Ibidem, s. 168.

${ }^{43}$ Ibidem.

${ }^{44}$ Ibidem.
} 
królowie powinni przestrzegać, inaczej mówiąc, powinny one być chronione przed arbitralną wolą rządzącego ${ }^{45}$.

W ujęciu Kalwina zasadnicze zadanie polityki polegało na zapewnieniu spójności społeczeństwa, na ochronie resztek naturalnego, społecznego instynktu człowieka. Naturalny instynkt towarzyski, okaleczony przez grzech pierworodny, nie był wystarczający, koniecznym stawał się element sztuczności w postaci instytucji władzy państwowej. Sprawnie funkcjonujące społeczeństwo było zatem produktem połączenia ludzkiej natury z rządem, wprowadzającym element sztuczności, służący korygowaniu niedoskonałości tej natury. Dla pojedynczego człowieka oznaczało to edukację dla ładu, nabycie cywilnych (obywatelskich) nawyków, służących życiu cywilizowanemu. Edukacja do członkostwa w uporządkowanej społeczności miała być wzmocniona działalnością kościoła, rozumianego jako społeczność wiernych, mającego intensywnie społeczny charakter ${ }^{46}$.

Paradoks myśli Marcina Lutra polegał na tym, że z jednej strony często wyrażał pogardę dla instytucji politycznych, a z drugiej wskazywał na potrzebę wezwania owego podejrzanego porządku politycznego do zadań dyscyplinujących społeczeństwo i kościół. Wiązało się to $\mathrm{z}$ jego koncepcją kościoła jako harmonijnej wspólnoty opartej na braterstwie, która nie mogła wygenerować władzy. Świecki rząd stał się w ten sposób jedyną siłą dyscyplinującą i integrującą tak w społeczeństwie, jak i w kościele ${ }^{47}$. Samemu Lutrowi i luteranom zabrakło odwagi do przeprowadzenia eksperymentu partnerstwa kościoła i państwa ${ }^{48}$. U luteranów, podobnie jak u anabaptystów, kategorie religijne i polityczne pozostawały w dialektycznym napięciu. Kościół, rozumiany jako święta wspólnota, kierująca się nakazami miłości, przeciwstawiony został polityce jako dziedzinie występku. Inaczej wyglądało to u Kalwina. Pragnął on przywrócenia reputacji porządku politycznego, przypominał protestantom społeczną stronę ich ludzkiej natury, która nie mogła się obejść bez polityki. Element polityczny w postaci władzy wprowadził również do kościoła, jego funkcja dyscyplinująca była taka sama jak w państwie. Kalwin zerwał z nauką Lutra traktującą porządek polityczny jako ośrodek represji, zbędny dla prawdziwego chrześcijanina (Kalwin zakładał bowiem, że nie sposób odgadnąć, kto owym prawdziwym, predestynowanym do zbawienia, chrześcijaninem jest).Jednostka została reintegrowana $\mathrm{w}$ dwóch porządkach: kościelnym i politycznym, oddzielonych od siebie, ale wzajemnie się dopełniających. Naprawiona została ciągłość pomiędzy zobowiązaniami religijnymi i politycznymi, zerwana przez wczesną reformację; cnoty chrześcijańskie i cnoty polityczne zostały do siebie przybliżone ${ }^{49}$.

\section{KALWINIZM I JEGO ZNACZENIE POLITYCZNE}

Termin „kalwinizm” pojawił się w latach sześćdziesiątych XVI wieku w polemikach kościołów reformacyjnych. Wprowadził go niemiecki luteranin Jaochim Westphal, chcąc określić teologiczne poglądy reformatorów szwajcarskich, w szczególności Kalwina. Odzwierciedlał on niepokój, jaki wśród luteranów na terenie Niemiec budziły rosnące

\footnotetext{
${ }^{45}$ Ibidem, s. 169.

${ }^{46}$ S.S. Wolin, op. cit., s. 163-164.

${ }^{47}$ Ibidem,s. $149-150$.

${ }^{48}$ G.A. Moots, The Protestant Roots of American Civil Religion, „Humanitas” 23/1-2 (2010), s. 78 i następne.

${ }^{49}$ S.S. Wolin, op. cit., s. $150-151$.
} 
wpływy teologii reformowanej. Był podjętą przez niemieckich luteranów próbą stygmatyzacji myśli Kalwina. Sam zainteresowany protestował przeciw takiemu określeniu, jednak śmiertelnie chory niewiele mógł już w tej kwestii zrobić. Określenie „kalwinizm”, odnoszące się do religijnego światopoglądu zwolenników Kalwina, sugeruje prostą relację pomiędzy Kalwinem a myślą jego kontynuatorów, jednak relacja ta jest złożona, a Kalwin nie był jedynym twórcą kalwinizmu, czyli tradycji reformowanej. Teologia Kalwina w tradycji reformowanej nie miała nigdy statusu normatywnego, w przeciwieństwie do spuścizny Lutra, cieszącej się wśród luterańskich wspólnotkonfesyjnych niepodważalną pozycją. Teologia reformowana była publicznie eksponowana w wieludokumentach, takich jak Pierwsza i Druga Konfesja Helwecka, Consensus Tigurinus (Konsensus z Zurichu), Katechizm Heidelberski, Belgijskie Wyznanie Wiary, Kanony z Dordt czy Standardy Westminsterskie. Dokumenty te wyrażały myśl kolektywną, były produktami określonych społeczności i okoliczności, w jakich te pierwsze się znalazły, nie eksponowały natomiast myśli żadnej indywidualnej osoby. Pojęcie kalwinizmu, ukute jako polemiczne narzędzie dla nadszarpnięcia reputacji protestantów reformowanych, nie stanowi dobrego narzędzia do analizy historii nowożytnej. Zdecydowanie lepiej służą temu określenia teologia reformowana albo reformowana ortodoksja, gdyż odzwierciedlają one fakt, że tak zwani kalwiniści kontynuowali myśl nie tylko samego Kalwina, ale także innych reformatorów, tworzących tradycję wyznań reformowanych. Kalwin był ważnym, choć ani jedynym, ani dominującym źródłem tej tradycji ${ }^{50}$. Posługiwanie się terminem „kalwinizm” w odniesieniu do całej teologii reformowanej jest dopuszczalne i wygodne, choć nie do końca poprawne, sugeruje bowiem ruch dotyczący przyswojenia przede wszystkim intelektualnego dziedzictwa Kalwina. Można wykazać, że teologowie z historycznego punktu widzenia określani jako kalwińscy w swoich poglądach zachowywali swobodę czerpania z teologicznych i metodologicznych źródeł innych niż pisma Kalwina. Jak napisał biograf reformatora z Genewy, Alister McGrath: „Kalwin mógł pozostawać najważniejszą z gwiazd na firmamencie kalwinizmu, jednak byli też inni, modyfikujący jego myśl i metodę własną myślą i metodą"51.

Pojęcie kalwinizmu może być również rozważane w oderwaniu od teologicznych korzeni jako historyczna siła, która w pewnej mierze przyczyniła się do ukształtowania nowoczesnego oblicza Zachodu. W tym ujęciu kalwinizm rozumie się jako moralny i społeczny depozyt wiary, uformowany pierwotnie przez religię, zachowujący jednak aktualność także bez niej. Depozyt ten można nazwać kalwinizmem świeckim ${ }^{52}$, który w ujęciu komparatywnym, podobnie jak kalwinizm teologiczny, cechował się zróżnicowaniem; nie w każdym społeczeństwie był tym samym. Szesnastowieczny Heidelberg, hugenocka Francja, siedemnastowieczna Holandia, purytańska Anglia, Szwajcaria i Szkocja - społeczeństwa tych krajów był kalwińskie, jednak zarazem na tyle zróżnicowane, by łatwe generalizacje nie były możliwe ${ }^{53}$.

\footnotetext{
${ }^{50}$ C.R. Trueman, Calvin and Calvinism, [w:]The Cambridge Companion to John Calvin, red. D.K. McKim, Cambridge University Press, Cambridge2004,s. 225-226.

${ }^{51}$ A.E. McGrath,Jan Kalwin. Studium ksztattowania kultury Zachodu, Semper, Warszawa 2009, s. 294.

${ }^{52}$ Ibidem, s. 286-289.

${ }^{53} \mathrm{H}$. Trevor-Roper, The Crisis of The Seventeenth Century. Religion, The Reformation, and Social Change, Liberty Fund, Indianapolis 1967, s. 189.
} 
Z pierwotnego i jedynego źródła suwerenności, jakim Kalwin uczynił Boga, wywodził trzy rodzaje suwerenności wtórnej: suwerenność państwa, suwerenność społeczeństwa i suwerenność kościoła.

Według tradycji biblijnej Adam i Ewa dali początek ludzkości, stąd ludzie pozostawali ze sobą w braterskiej więzi. Ta organiczna jedność obejmowała ludzi żyjących we wszystkich trzech wymiarach czasowych: obecnie, w przeszłości i w przyszłości, lecz zniszczona została przez grzech pierworodny ${ }^{54}$. Stąd -jak wierzył Kalwin -brały się egoizm i żądza panowania jednych nad drugimi, zakłócające harmonię równości i pokoju, dzielące ludzkość podług państw i narodów. Jak wiadomo, w obliczu upadku pierwszych ludzi, państwo dane zostało przez Boga jako rodzaj środka ochraniającego słabych i sprawiedliwych oraz dyscyplinującego silnych i złych. W przeciwieństwie do społeczeństwa, mającego charakter naturalny, państwo jest tworem sztucznym, swoistym ciałem obcym. Relacje między nim a społeczeństwem cechuje stałe napięcie, generowane $\mathrm{z}$ jednej strony lękiem społeczeństwa przed nadużyciem władzy przez rządzących, z drugiej -obawą rządzących przed rewoltą społeczeństwa. Jest to $\mathrm{w}$ istocie napięcie pomiędzy dwiema wartościami: władzą uosabianą przez państwo i wolnością, będącą udziałem naturalnego społeczeństwa. Charakter państwa cechuje ambiwalencja: rządzący jako ludzie pozostają podatni na pokusy, zwłaszcza na pokusę nieograniczonej władzy, z drugiej jednak strony, biorąc pod uwagę kondycję ludzką, bez rządu i prawa ludzki świat byłoby autentycznym chaosem.

W świetle kalwinizmu instytucja państwa jest dobrodziejstwem, chroniącym naturalne elementy, jakimi są życie i wolność, zarazem stanowi jednak dla tych wartości nieustanne zagrożenie $^{55}$. Kalwinizm uczy, że społeczeństwo uznające jedynie zwierzchność Boga było pierwotne $\mathrm{w}$ stosunku do państwa. Ustanowienie państwa rozumiane jako wyraz bożej woli pociągało za sobą wymóg posłuszeństwa władzy przez to państwo reprezentowanej, rozumianego nie jako strach przed karą, ale w kategoriach sumienia (posłuszeństwo władzy równało się posłuszeństwu Bogu) ${ }^{56}$.Traktując Boga jako suwerena, Kalwin zaprzeczał idei suwerenności ludu, determinującej traktowanie woli człowieka jako źródła zasad, także politycznych. W jego przekonaniu byłby to fakt detronizacji Boga przez człowieka. Według Abrahama Kuypera Kalwin, stawiając człowieka i lud bezpośrednio przed obliczem Stwórcy, przyczynił się do podtrzymywania cennych ludzkich aspiracji, które narażone zostały w związku ze sztuczną i mechaniczną naturą państwa, kolidującą $\mathrm{z}$ naturalnym charakterem ludzkich społeczności. Wiążąc władzę z prawem natury, czyli w istocie z boskim Objawieniem, posłuszeństwo wobec niej czynił łatwiejszym, co skutkowało zastąpieniem posłuszeństwa wymuszonego strachem, posłuszeństwem kierowanym nakazami sumienia ${ }^{57}$.

Antyteza pomiędzy sztucznym charakterem państwa a naturalnym charakterem społeczeństwa nie wiązała się $\mathrm{z}$ traktowaniem tego ostatniego jako całości, lecz jako konglomeratu złożonego z ukształtowanych organicznie, autonomicznych sfer: gildii reprezentujących suwerenność zawodową, uniwersytetów (suwerenność naukowa) czy akademii (suwerenność estetyczna). Każda z tych sfer dysponowała niezależnym osądem

${ }^{54}$ A. Kuyper, Lectures on Calvinism, WM. B. Eerdmans Publishing Company, Grand Rapids 1931, s. 79-80.

${ }^{55}$ Ibidem, s. 81.

${ }^{56}$ Ibidem, s. 81-83.

${ }^{57}$ Ibidem, s. 90. 
i działaniami w sferze dla siebie właściwej. Poza tymi sferami istniała jeszcze rodzina $\mathrm{z}$ prawem małżeństwa, pokoju domowego i posiadania, również suwerenna, nie $\mathrm{z}$ przyzwolenia rządu, ale z postanowienia Boga. Nie należało zapominać o wioskach i miastach, tworzących własne sfery egzystencji. Jak zauważył Abraham Kuyper, do wymienionych sfer społecznych władza rządu nie sięgała, ograniczała ją suwerenność społeczna, równa pierwszej $\mathrm{w}$ jej boskim pochodzeniu ${ }^{58}$. Konsekwencją dualnego charakteru ludzi jako istot $\mathrm{z}$ natury społecznych, a z konieczności politycznych, było nieustanne napięcie, związane $\mathrm{z}$ próbami rządu wkraczania $\mathrm{w}$ sferę społeczną, $\mathrm{w}$ suwerenność samego naturalnego życia, regulowania go i podporządkowywania ${ }^{59}$.

Myśl Kalwina wyrastała ze świadomości wszechobecności grzechu w ludzkim świecie. Stąd potrzeba władzy w państwie i w kościele, choć odrębnej dla każdej z tych instytucji, oraz wypracowania równowagi pomiędzy suwerennościami państwa i społeczeństwa, wywodzącymi się z jednego, boskiego źródła.

Kalwin żył w czasach zupełnie innych niż my, kiedy religia, zatroskanie o zbawienie duszy po śmierci, były dla ludzi niepomiernie ważniejsze niż współcześnie. Jego podejście do polityki oparte było na innych niż nasze założeniach. Kalwin żył przede wszystkim religią, stanowiła ona dla niego punkt wyjścia do rozważań na każdy temat. W jego filozofii życie, prawo, polityka przesiąknięte są religią. Z prawa bożego wywodził wszystkie rodzaje prawa, wtym prawo natury, na którym miało opierać się funkcjonowanie polityki. Rozróżnienie pomiędzy prawem bożym objawionym w Biblii, stanowiącym podstawę życia religijnego, a prawem bożym w postaci prawa natury, odnoszącym się do życia doczesnego, w tym politycznego, było istotnym osiągnięciem teoretycznym. Rozdział łaski bożej i natury posłużył do rozdzielenia kościoła od państwa i zapoczątkował kształtowanie się sfery świeckiej, charakterystycznej dla nowoczesności. Biblijna opowieść o upadku Adama stanowiła podstawę protestanckiego przekonania, że łaska nie uzupełnia już natury, ale stała się jej przeciwieństwem. Świadomość wszechobecności grzechu w ludzkim świecie stanowiła dla Kalwinadostateczny powód dla zasady kontroli i równowagi władzy. Religijne źródło w filozofii Kalwina ma również sprzeciw wobec rządów tyrańskich, godzących w sprawiedliwość Boga, a zatem i ludzi. Choć nie wszystkie z poglądów reformatora mogłyby obecniespotkać się z aprobatą, to jednak jegopodstawowe idee, takie jak idea ograniczonego rządu, kontrolowanego przez wybieralnych magistratów, czy pasja dla sprawiedliwości, pozostają kluczowe dla współczesnego systemu wartości politycznych.

\section{LITERATURA}

[1] Calvin J., Commentary on the Book of Psalms, thum. Rev. J. Anderson, Vol. 4, Christian Classics Ethereal Library, Grand Rapids,http://www.ccel.org/ccel/calvin/calcom11.pdf, 23.04.2013.

[2] Calvin J., Commentary on Daniel, Vol. 1, Ch. 4, http://www.biblestudyguide.org/ebooks/comment/calcom24.pdf, 23.09.2010.

[3] Calvin J., Institutes of the Christian Religion, thum. H. Beveridge, Hendrickson Publishers, Peabody 2008.

[4] Hervada J., Historia prawa naturalnego, Petrus, Kraków 2013.

\footnotetext{
${ }^{58}$ Ibidem, s. 90-91; 95-96.
}

${ }^{59}$ Ibidem, s. 93-94. 
[5] History of Political Philosophy, red. L. Strauss, J. Cropsey, Rand McNally, Chicago 1963.

[6] Koetsier L.S., Natural Law and Calvinist Political Theory, Trafford Publishing, Bloomington 2004.

[7] Kuyper A., Lectures on Calvinism, WM. B. Eerdmans Publishing Company, Grand Rapids 1931.

[8] McGrath A. E., Jan Kalwin. Studium kształtowania kultury Zachodu, Semper, Warszawa, 2009.

[9] Moots G. A., The Protestant Roots of American Civil Religion, "Humanitas", 2010, Vol. 23, Iss., 1-2.

[10] Skinner Q., The Foundations of Modern Political Thought, Vol.2:The Age of Reformation, Cambridge University Press, Cambridge2004.

[11] Stevenson W.R. Jr., Calvin and Political Issues, [w:]The Cambridge Companion to John Calvin, red. D. K. McKim, Cambridge University Press, Cambridge 2004.

[12]Trevor-Roper H., TheCrisis of The Seventeenth Century. Religion, The Reformation, and SocialChange, Liberty Fund, Indianapolis 1967.

[13]Trueman C.R., Calvin and Calvinism, [w:]The Cambridge Companion to John Calvin, red. D.K. McKim, Cambridge University Press, Cambridge 2004.

[14]Wolin Sh.S., Politicsand Vision. Continuity and Innovation in Western Political Thought, Princeton University Press, Princeton 2006.

\section{THE POLITICAL PHILOSOPHY OF JOHN CALVIN}

This article presents the elements of the political philosophy of John Calvin tied with his theology contained primarily in his main work Institutes of the Christian Religion. The assumption of omnipotence of God was for him the starting point for the discussion on the non-religious issues, such as the nature of society, the state, or the problem of abuse of political power. Calvin's thought had a significant impact on the development of modern politics, has given rise to separation of church and state and to the development of secular sphere The starting point for these considerations was the doctrine ofpostlapsarianism and its result as a radical separation between the supernatural (the sphere of grace) from the sphere of the earth (nature). Although Calvin did not create a comprehensive system of the nature law his reflections on this issue significantly influenced the political thinking. If we assume that modern political philosophy begins with the rejection of Revelation and reliance solely on the reason, we can conclude that John Calvin as a theologian does not have any connection with her. However, the opposite point of view assumes, that the knowledge of modernity is not possible without dipping into the Calvinistic religious tradition. It is believed that what was sown as the Reformation sprouted politically as anti-royal, libertarian movement. Between these two extreme positions there is the whole spectrum of intermediate positions, according to which Calvin's theology and its associated political philosophy played an important, but by no means the only role in the development of modern politics. This article is located in that spectrum.

Keywords: John Calvin, commonwealth, authority, God's grace, law of nature.

DOI:10.7862/rz.2015.hss.30

Przesłano do redakcji: październik 2014

Przyjęto do druku: październik 2015 